\title{
MJMR THE EFFECT OF GIVING EEL FLOUR (MONOPTERUS ALBUS) WITH LEVELS TO THE ACCELERATION OF FRACTURE HEALING PROCESS AT RATTUS NOVERGICUS WISTAR ALBINO JANTAN
}

\author{
Yesi Maifita ${ }^{1 *}$, Zuriati $^{2}$, Rena Oktafiyanti ${ }^{2}$ \\ ${ }^{1}$ Lecturer of PialaSaktiPariaman- Indonesia \\ ${ }^{2}$ Lecturer of Binawan University Jakarta- Indonesia \\ *Corresponding Author's Email: 28yesimaifita@gmail.com
}

\begin{abstract}
World Health Organization (WHO) noted that there were more than 2 million people who suffered from fractures in 2017. The comparison of the results of the 2007 Riskesdas with the 2013 Riskesdas showed a tendency to increase fracture prevalence from $7.5 \%$ to $8.2 \%$ (Riskesdas, 2013). (Sabiton, 2016) says that fracture treatment can be done by recognition, reduction, retention and rehabilitation. According to (Faizah, 2015) Nutrients that contain high protein according to the needs can help the fracture healing process. Eels have a lot of nutrients, such as phosphate, calcium, protein, collagen and amino acids that can help bone growth. The purpose of the study was to determine the effect of giving eel flour (Monopterus Albus) with multilevel content to the acceleration of male healing process of Rattus Novergicus Fracture of Wistar Albino. This research is an experimental study with post test only control group design. This research was conducted in May-June 2019 in the Laboratory of Anatomy of Stikes Piala Sakti Pariaman. The sampling technique was purposive sampling technique with many samples 24 rats. The results of the ANOVA test have the effect of giving eel flour to the acceleration of the fracture healing process with a value of $=0,000$, followed by Post Hoc LSD to determine the test of significant differences between groups. The higher the dose of flour, the faster the fracture healing process. Based on the results of the study it can be concluded that consuming eel flour can accelerate the process of fracture healing. Need to do further testing to humans as an effort to test the safety of the dose.
\end{abstract}

\section{Keywords: Eel flour, Fracture}

\section{INTRODUCTION}

World Health Organization (WHO), noted that there were more than 2 million people who were recorded as having suffered a fracture in 2017. Of some parts of the world, Africa has the highest incidence of fractures due to traffic accidents (26.6\%), while regions Europe has the lowest accident incidence due to accidents as much as $(9.3 \%)(\mathrm{WHO}, 2017)$

The prevalence of fractures in Indonesia is $15.3 \%$, with the highest prevalence found in South Sulawesi $(12.8 \%)$ and the lowest in Jambi $(4.5 \%)$. There are in West Sumatra itself (5.8\%). Comparison of the results of (Riskesdas, 2007 with Riskesdas, 2013) showed a tendency to increase the prevalence of fractures from $7.5 \%$ to $8.2 \%$ (Badan Penelitian dan Pengembangan Kesehatan, 2013). Data from the Health Department of
West Sumatra Province (West Sumatra Health Office) in 2014 found that around 2700 people experienced a fracture incident, 24\% experienced a death, 15\% experienced a cure and $5 \%$ experienced a psychological disorder or depression in the event of a fracture (Kemenkes, 2014) fracture is a continuation of bone structure continuity, not only the separation of the cortex, the fracture also results in complete damage and separate bone fragments (Kammerlander, Erhart, Doshi, Gosch \& Blauth, 2013).

Fractures can be caused by traumatic injuries, traffic accidents and are caused by degenerative factors (Sagaran et al., 2017). The impact of fracture according to (Dewi, 2017), is impairment of mobilization, stress, mental disorders, compartment syndrome, arterial damage. Nurses not only collaborate with other health teams, but they can identify and provide nursing 
interventions and evaluate the implementation(Suriya \&Zuriati, 2019)

(Sabiton, 2016) says that fracture management can be done by recognition, reduction, retention and rehabilitation. The action is to restore the location of fragments, hold bone fragments and restore bone as much as possible and can only be done in a hospital. Meanwhile According to (Faizah, 2015) Nutrients containing high protein in accordance with needs can help the fracture healing process(Mahartha, Maliawan, \& Kawiyana, 2013).

Eels have a lot of nutrients, such as phosphate, calcium, protein, collagen and amino acids that can help bone growth. Consuming adequate protein can help bone density; collagen can accelerate bone matrix formation. Amino acids can help the process of activating osteoblasts. Calcium and phosphate can accelerate bone re-absorption for the formation of fibrous connective tissue (Mintarsih, 2015).

The results of this study are expected to provide information in nursing as a promotive and preventive aid in helping accelerate the fracture healing process. And can be used as a foundation for further testing to humans.

\section{METHODOLOGY}

This type of research is an experiment with a post test only control group design research design that is a design used to measure the effect of treatment in the experimental group by comparing treatment results with the control group ending the treatment period. The treatments consisted of control groups, groups P1, P2, and $\mathrm{P} 3$. The control group as a group without treatment, P1 eel flour at a dose of $50 \mathrm{mg} / \mathrm{kgBW}, \mathrm{P} 2$ eel flour at a dose of $100 \mathrm{mg} / \mathrm{kgBW}, \mathrm{P} 3$ eel flour at a dose of $200 \mathrm{mg}$ $/ \mathrm{kgBW}$.

The study was conducted in May 2019. The population of this study was rats (Rattus Novergicus Strain Wistar) obtained from the experimental animal rearing unit. With a large sample of 24 rats To anticipate drop out during treatment, $10 \%$ of the total sample in each treatment group was exceeded, so that the number of rats was 28 . For the control group, there were 7 cages, and there were 3 cages in the treatment group with 7 cages. So that the total number of rats during the study were 28 .
Before the research began, the preparation of tools and materials first included, eels, mice, mouse cages, rat drinking water, feed mice, surgical sets, chloroform, syringes, husks, gastric sonde, digital scales.

\section{Procedure}

\section{Preparation Stage}

a. Experimental Animals

Test animals as many as 28 male rats with 2-3 months of age, body weight 200-4 grams to be broken bones. Rats that met the criteria were adapted in the laboratory by being staged, fed and drinking.

\section{b. Eel Flour Making}

For making eel flour, the eel is cleaned and cut into \pm 3 $\mathrm{cm}$ pieces. Eels that have been cut are dried in the sun to dry. After that, the eel meat is crushed using a grinder. When it's smooth, dissolve the eel flour with hot water.

\section{Work Procedure}

Test animals as many as 28 male rats with 2-3 months of age, body weight 200-4 grams. Rats that met the inclusion criteria were adapted in the laboratory by being kept in cages and grouped into four groups. Giving eel flour in mice was carried out by using gastric sonde at a dose of $50 \mathrm{mg} / \mathrm{kgBB}, 100 \mathrm{mg} / \mathrm{kgBB}$, and $200 \mathrm{mg} / \mathrm{kgBB}$ in groups $\mathrm{P} 1, \mathrm{P} 2$, and P3.

At the end of the study, mice were sacrificed for their bones. Bone is removed by dissection to see the acceleration in the healing process of the fracture.

\section{RESULT}

The results of the study were conducted data tabulation and data analysis using computerization with normality testing using Shapiro-wilk, after the data were normally distributed, then proceed with the One Way Anova test.

Table 1: Average Time to Accelerate the Fracture Healing Process in Rats

\begin{tabular}{|c|c|c|}
\hline Group & Mean \pm SD & P value \\
\hline Control & $15 \pm 0.89$ & \multirow{2}{*}{0.00} \\
\hline Intervention 1 & $13 \pm 0.89$ & \\
\hline Intervention 2 & $10 \pm 0.89$ & \\
\hline Intervention 3 & $7.67 \pm 0.81$ & \\
\hline
\end{tabular}


From the results of analytical tests using Annova, there was an acceleration in the average healing process of the fracture between the control group and the treatment group. After analyzing the use of One Way Annova, it is known that a $p$ value of 0.00 can be concluded that there is a significant influence on the administration of eel flour (MonopterusAlbus) to the acceleration of the fracture healing process.

The results of this study are supported by the results of previous studies by (Hayasi et al., 2014). This study was conducted on experimental animals and it is known that elcalcitonin in eels has the ability to heal in fractures by induction, and the effectiveness of healing elcalcitonin in eels is known to be higher when compared to salmon and pork. From this study it was also confirmed that the ability of elcalcitonin was not only to cure but also preventive, it was proven that the power of elcalcitonin against fractures due to inductive osteoporosis in experimental animals had a significant influence in terms of photometric analysis of bone tissue of experimental animals. According to (Hardhono, 2016) based on the results of the analysis of the adequacy level of animal protein has a significant relationship with bone density so that it is good for growth and repair of broken bones.

Eels have a lot of nutrients, such as phosphate, calcium, protein, collagen and amino acids that can help bone growth. Consuming adequate protein can help bone density, while collagen can accelerate the formation of bone matrix and amino acids can help the process of osteoblast activation and calcium and phosphate can accelerate bone reabsorption for the formation of fibrous connective tissue (Suwandi, 2015).

Protein value in eels (18.4 g / $100 \mathrm{~g}$ meat).Higher than egg protein $(12.8 \mathrm{~g} / 100 \mathrm{~g})$. Like other types of fish, the digestibility value of protein in eels is also very high, so it is suitable for protein sources for all age groups, from infants to old age. (Winarno, 2015)

The quality of a protein can be assessed from the ratio of amino acids that make up the protein. The results of the analysis of fresh eel amino acids found 15 amino acids consisting of 9 essential amino acids and 6 nonessential amino acids. The essential amino acids found in fresh eels are histidine, threonin, tyrosine, methionin, valine, phenylalanine, I-leucin, leucin, and lysine. Leucine and isoleucine are essential amino acids that are very necessary for the growth of children and maintain nitrogen balance in adults. Leucine is also useful for reforming and building muscle protein (Faizah \& Fitranti, 2015)

Eel's nonessential amino acids are aspartic acid, glutamic acid, serine, glycine, arginine, and alanine. The highest non essential amino acid in fresh eel is glutamic acid which is $12.89 \mathrm{~g} / 100 \mathrm{~g}$, while the highest essential amino acid is lysine which is $7.13 \mathrm{~g} / 100 \mathrm{~g}$. The limiting amino acid in fresh eels is histidine which is $1.54 \mathrm{~g} / 100 \mathrm{~g}$. (Astiana, Suwandi, Ashory Suryani \& Hidayat, 2015).

LSD Post Hoc Test, it is known that the acceleration of the fracture healing process has a significant difference. The faster healing process of fracture was found in the P3 group with an average of 7.67 days, while the longest was found in the P1 group with 15 days and P2 with 10 days, this means that the greater the dose of eel flour given, the faster the healing process of fracture with a dose of p $150 \mathrm{mg} / \mathrm{kgBB}, \mathrm{P} 2100 \mathrm{mg} / \mathrm{kgBB}$, and P3 $200 \mathrm{mg} / \mathrm{kgBB}$.

Looking at the results of research statistics there are differences in the mean of each group of each variable. The results of the Post Hoc Test also showed that there were significant differences between the control group and the administration of eel flour. This result is influenced by variations in the data with the treatment group consisting of 6 samples.

The results of this study were strengthened by (Ganong, 2014) saying that bones had mineral additions through bone remodeling mycenism. The healing process of fractures includes the process of bone reabsorption by osteoclasts and the formation of bone matrix by osteoblast cells and is assisted with the intake of nutrients such as protein, collagen, calcium, and phosphorus contained in eels(Barret, Barman, Boitano, $\&$ Brooks, 2014).

From the description above it can be concluded that the performance of the eel flour to accelerate the fracture healing process. Increased bone formation due to the effects of protein, collagen, amino acids, calcium and phosphate from eels and increased performance of osteoblasts that cause the process of bone formation, bone matrix will increase. 


\section{CONCLUSION}

Based on the results of this study it can be concluded that:

1. Eel flour has a significant effect on the acceleration of the fracture healing process.

2. The dose of $200 \mathrm{mg} / \mathrm{kg}$ body weight of eel flour is the highest dose and affects the process of accelerating the fracture faster compared to $100 \mathrm{mg} / \mathrm{kg}$ body weight, and $50 \mathrm{mg} / \mathrm{kg}$ body weight

\section{Conflict of Interest}

The authors declare that they have no conflict of interest.

\section{ACKNOWLEDGEMENT}

None

\section{REFERENCES}

Astiana, I. N., Suwandi, R., Ashory Suryani, A., Hidayat, T. (2015). Pengaruh penggorengan belut sawah (Monopterus albus) terhadap komposisi asam amino, asam lemak, kolesterol dan mineral. DEPIK. https://doi.org/10.13170/depik.1.1.2366

Badan Penelitian dan Pengembangan Kesehatan. (2013). Riset Kesehatan Dasar 2013. Riset Kesehatan Dasar 2013.

Barret, K. E., Barman, S. M., Boitano, S., Brooks, H. L. (2014). Buku ajar fisiologi kedokteran ganong. Penerbit Buku Kedokteran EGC.

Faizah, L. N., Fitranti, D. Y. (2015). Hubungan Asupan Protein, Fosfor, Dan Kalsium Dengan Kepadatan Tulang Pada Wanita Dewasa Awal. Journal of
Nutrition College.

Kammerlander, C., Erhart, S., Doshi, H., Gosch, M., Blauth, M. (2013). Principles of osteoporotic fracture treatment. Best Practice and Research: Clinical Rheumatology. https://doi.org/10.1016/ j.berh.2014.02.005

Kemenkes. (2014). Profil Kesehatan Provinsi Sumatera Barat 2014. Dinas Kesehatan Prop Sumbar.

Mahartha, G. R. A., Maliawan, S., \& Kawiyana, K. S. (2013). Manajemen Fraktur Pada Trauma Muskuloskeletal. E-Jurnal Medika Udayana.

Mintarsih, S. dan N. (2015). PENGARUH LATIHAN RANGE OF MOTION TERHADAP PENINGKATAN KEMAMPUAN FUNGSI EKSTREMITAS SENDI LUTUT PADA PASIEN POST OPERASI (ORIF) FRAKTUR FEMUR THE. In Seminar Nasional Hasil - Hasil Penelitian dan Pengabdian LPPM Universitas Muhammadiyah Purwokerto,

Sagaran, Chandra, V., Manjas, Menkher, Rasyid, \& Rosfita. (2017). Distribusi Fraktur Femur Yang Dirawat Di Rumah Sakit Dr. M. Djamil, Padang (2010-2012). Jurnal Kesehatan Andalas.

Suriya, M., \& S. Zuriati. (2019). the Effect of Rose Aromatherapy on Reducing the Post-Operative Pain Scale in Aisyiyah Padang Hospital, West Sumatera, Indonesia. International Journal of Advancement in Life Sciences Research, 2(1), pp:11-15.

WHO. (2017). WHO | World Heart Day 2017. WHO 